\title{
TUTKITUN TIEDON TEEMAVUOSI 2021
}

Oxfordin sanakirja valitsi "post-truthin" vuoden 2016 sanaksi, osaltaan Yhdysvaltain presidentinvaalien ja Brexit-kampanjoinnin kirittämänä. Totuudenjälkeisellä viitataan tilanteeseen, jossa tunteisiin ja henkilökohtaisiin käsityksiin vetoaminen on tehokkaampi tapa vaikuttaa yleiseen mielipiteeseen kuin faktapohjainen argumentointi. Tai kuten suomalaispoliitikko sen vuonna 2015 kiteytti: "Onko tarina tosi tai ei, se on toinen juttu. Näin nämä asiat koetaan.”

Käsite on vuonna 2020 ajankohtainen ja sivuuttamaton osa yhteisen todellisuuden rakentumista (post-truth politics). Vaalituloksesta katkeroitunut Yhdysvaltain väistyvä presidentti on pitänyt yllä villejä salaliittoteorioita samaan aikaan kun QAnonin kenttäväki raportoi tunnelisodan etenemisestä mantereita yhdistävien käytävien labyrintissä.

\section{$* * *$}

Vuosi 202 I on tutkitun tiedon teemavuosi Suomessa. Tiedebarometri on mitannut kansalaisten luottamusta tieteeseen seitsemän kertaa 2000-luvun aikana, viimeksi vuonna 2019. Sen perusteella mikään ei viittaa siihen, että kansalaisten usko tieteeseen olisi laajamittaisesti horjumassa. Koulutus nähdään yhä keskeisenä osana kansallista narratiivia.

Mutta mitä on tieteellinen, tutkittu tieto? Mikä erottaa sen muunlaisesta tiedosta ja henkilökohtaisista käsityksistä? Mitä tieteellä ymmärretään? Tiedebarometrissä tällaiset kysymykset jäävät kysymättä, mutta tutkitun tiedon teemavuotena ne ovat avainkysymyksiä.
Koronapandemia on kaiken muun ohella nostanut esiin myös tiedettä ja tieteellistä prosessia. Avoin tiede, vertaisarviointi, tieteellinen menetelmä ja tieteellisen kommunikaation erityispiirteet ovat saaneet lääke- ja rokotetutkimuksen kylkiäisenä tilaa valtamediassa. Tieteellisen tiedon päivittyvä ja itseäänkorjaava luonnekin on saattanut tulla jossain sivulauseessa tutuksi.

Tiedon luonteen ohella teemavuoden tavoitteet korostavat tutkitun tiedon näkyvyyttä, saavutettavuutta ja vaikuttavuutta. Nämä ovat aiheita, joiden parissa tieteellisissä kirjastoissa ja tietopalvelualalla työskennellään joka päivä. Metadata- ja kokoelmatyön sekä tiedonhankinnan ja tutkimuksen palveluiden kautta kirjastot tarjoavat perusinfrastruktuurin tiedon hyödyntämiselle.

Tutkitun tiedon saavutettavuus ja vaikuttavuus ovat esillä tässäkin lehdessä. Eduskunnan kirjaston tietotukihanketta käsittelevä artikkeli avaa sitä, miten tutkittua tietoa tuodaan osaksi päätöksentekoa - ja mikä rooli tietopalveluilla on tässä. Tietopalveluiden merkitys nousi esiin myös valtioneuvoston kanslian viimevuotisessa selvityksessä, Tutkimustiedon hyödyntämisen hyvät käytännöt lainvalmistelussa: kohti parempaa sääntelyä?

Lehdestä löytyy myös laaja katsaus kirjastojen datapalveluihin. Tutkitun tiedon parempi saavutettavuus ja hyödyntäminen on näidenkin palveluiden perimmäinen tavoite: kirjastojen palvelut ja koulutukset pohjustavat tietä tiedon jakamiseen ja sitä kautta tutkitun tiedon vaikuttavuuteen.

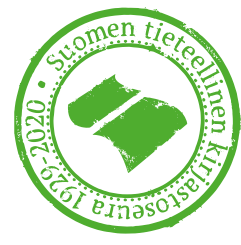

